\title{
PERBANDINGAN POLA SENSITIVITAS BAKTERI TERHADAP ANTIBIOTIK ANTARA RUANG ICU DAN NON ICU DI RUMAH SAKIT UMUM DAERAH DR. H. ABDUL MOELOEK PROVINSI LAMPUNG PERIODE JANUARI-MARET TAHUN 2019
}

\author{
Hidayat1, Upik Febriani2, Wirawan Anggotomo³, M Agung Kurnia ${ }^{4}$ \\ ${ }^{1}$ Kepala Instalasi Laboratorium Patologi Klinik RSUD Dr.H Abdul Moeloek Provinsi \\ Lampung \\ ${ }^{2}$ Departemen Anatomi Fakultas kedokteran Universitas Malahayati Lampung \\ ${ }^{3}$ Staf Pengajar Fakultas Kedokteran Universitas Malahayati Lampung \\ ${ }^{4}$ Program Studi kedokteran Fakultas Kedokteran Universitas Malahayati Lampung
}

[email korespondensi: Kurniaa100@gmail.com]

\begin{abstract}
Comparison Of Bacterial Sensitivity Patterns Against Antibiotics Between ICU And Non ICU Spaces In The General Hospital Of Dr. H. Abdul Moeloek Lampung Province Period January-March 2019. The use of irrational antibiotics can cause resistance in hospitals, especially in intensive care units. This study aims to determine the differences in the comparative pattern of bacterial sensitivity to antibiotics between the ICU and non ICU rooms in Dr. H. Abdul Moeloek Hospital, Lampung Province. The research method is descriptive analytic using a retrospective approach. The samples in this study were 284 in the microbiology section of the clinical Pathology laboratory in Dr. H. Abdul Moeloek Lampung Province. Univariate statistical test. Results Culture patterns based on culture in the period of January 2019, namely in the non-ICU room Enterobacter sp, which were 51 samples and Klebsiella pneumoniae, 9 samples. In the ICU room were Enterobacter cloacea, 68 samples, Klebsiella sp, 34 samples, Proteus mirabilis, 16 samples, and Escherichia coli, 15 samples. Conclusion The most germicidal pattern in the ICU room was Enterobacter cloacea, the highest sensitivity to amikacin, while the non ICU room was Enterobacter sp, the highest sensitivity to the antibiotic netilmycin.
\end{abstract}

Keywords: Bacterial Sensitivity Pattern, Antibiotics, ICU, non ICU

\begin{abstract}
Abstrak: Perbandingan Pola Sensitivitas Bakteri Terhadap Antibiotik Antara Ruang ICU Dan Non ICU Di Rumah Sakit Umum Daerah Dr. H. Abdul Moeloek Provinsi Lampung Periode Januari-Maret Tahun 2019. Penggunaan antibiotik yang irasional dapat menyebabkan timbulnya resisten di Rumah sakit terutama di unit perawatan intensif. Penelitian ini bertujuan untuk mengetahui perbedaan perbandingan pola sensitivitas bakteri terhadap antibiotik antara ruang ICU dan non ICU di RSUD Dr H. Abdul Moeloek Provinsi Lampung. Metode penelitian ini deskriptif analitik menggunakan pendekatan retrospektif. Sampel pada penelitian ini 284 dibagian mikrobiologi laboratorium Patologi klinik di RSUD Dr. H. Abdul Moeloek Provinsi Lampung. Uji statistik univariat. Hasil Pola kuman berdasarkan kultur pada periode bulan januari- maret 2019 yaitu di ruang non ICU Enterobacter $s p$ yaitu 51 sampel dan Klebsiella pneumoniae yaitu 9 sampel. Di ruang ICU adalah Enterobacter cloacea yaitu 68 sampel, Klebsiella sp yaitu 34 sampel, Proteus mirabilis yaitu 16 sampel, dan Escherichia coli yaitu 15 sampel. Kesimpulan Pola kuman terbanyak di ruang ICU adalah Enterobacter cloacea sensitivitas tertinggi terhadap amikacin sedangkan ruang non ICU adalah Enterobacter $s p$ sensitivitas tertinggi terhadap antibiotik netilmycin
\end{abstract}

Kata kunci: Pola Sensitivitas bakteri, Antibiotik, ICU, non ICU 


\section{PENDAHULUAN}

Antibiotik adalah zat kimia yang memiliki khasiat menghambat atau mematikan Pertumbuhan dan perkembangan Mikroorganisme, sedangkan efek racun bagi manusia relatife kecil (Tjay dan rahardja, 2007).

Penggunaan antibiotik yang tidak rasional dapat menyebabkan timbulnya kuman resisten di Rumah sakit terutama di unit perawatan intensif. (Septi D, 2015).

Menurut Departemen Kesehatan dan Layanan Masyarakat Amerika Serikat yang berbasis di DeKalb County, setiap tahun terdapat dua juta orang yang telah resisten terhadap antibiotik dan setidak nya 23.000 orang meninggal dunia akibat dari resistensi antibiotik Data menunjukkan $86 \%$ rumah tangga menyimpan antibiotik tanpa resep, provinsi Lampung menjadi yang tertinggi kedua yaitu $92 \%$ rumah tangga penyimpan antibiotik setelah Kalimantan Tengah 93,4\%. (Rikesdas, 2013).

Studi yang telah dilakukan di Indonesia sejak tahun 1990 sampai dengan tahun 2010 mengenai resistensi antibiotik, resistensi sudah terjadi hampir pada semua bakteri bakteri patogen penting. Hal tersebut merupakan dampak negatif dari pemakaian antibiotik yang irasional, penggunaan antibiotik dengan indikasi yang tidak jelas, dosis atau lama pemakaian yang tidak sesuai, cara pemakaian yang kurang tepat, status obat yang tidak jelas, serta pemakaian antibiotik secara berlebihan. (WHO,2011).

Seperti yang selama ini kita ketahui, rumah sakit adalah tempat untuk mencari perawatan. Namun rumah sakit juga menjadi sarang bagi berbagai macam bakteri, sementara pasien di ICU seringkali dalam keadaan munocompromise, tindakan dan monitoring secara invasife, dan seringnya kontak antara staf rumah sakit dan pasien menyebabkan munculnya infeksi. Tingginya penggunaan antibiotik juga menyebabkan resistensi, yang akan menyulitkan terapi dan mempermudah penyebaran infeksi (Ni Nengah DF, 2016).
Intensive Care Unit (ICU) adalah unit perawatan komprehensif. ICU memiliki fungsi utama yaitu untuk melakukan tindakan perawatan pada pasien gawat darurat dan untuk mendukung keadaan organ vital dari pasien yang akan menjalani operasi elektif atau prosedur intervensi dan berisiko tinggi (WHO, 2015).

Pasien-pasien yang dirawat di ICU yang mempunyai pertahanan tubuh yang rendah, monitoring keadaan secara invasif, terpapar dengan berbagai jenis antibiotik dan terjadi kolonisasi oleh bakteri resisten. Mengakibatkan pasien yang dirawat mempunyai potensi yang lebih besar mengalami infeksi. Dari data didapatkan yang memiliki pertumbuhan kuman paling banyak yaitu pada ruang ICU sebanyak 14,6\%. Data dari 5 jenis sampel yaitu, darah, pus, urin, sputum, cairan tubuh. Enterobacter sp Kuman paling banyak ditemukan di ruang ICU karena banyak ditemukan infeksi yang terkontaminasi dengan sumber bakteri patogen (Zahra M, 2018).

Penelitian yang dilakukan pada pasien yang dirawat di ICU RSUP Sanglah Denpasar, mikroorganisme yang banyak ditemui adalah Pseudomonas aeruginosa (18\%), Acinetobacter baumanii (18\%), Staphylococcus koagulase negatif $(12 \%)$, Candida spp (10\%), dan Staphylococcus aureus (8\%).

Pada isolat bakteri yang ditemui pada pasien, didapatkan bahwa bahwa Vancomycin dan Linezolid merupakan antibiotik yang sensitif untuk melawan infeksi bakteri gram positif. Untuk mengobati infeksi bakteri gram negatife, Cefoperazone/Sulbactam, Tazobactam, Meropenem, dan Cefepime dapat menjadi pilihan (Ni Nengah DF, 2016).

\section{METODE}

Penelitian dilakukan di bagian mikrobiologi Laboratorium Patologi Klinik RSUD DR. H. Abdul Moeloek Provinsi Lampung mulai bulan OktoberNovember tahun 2019. Penelitian ini termasuk dalam jenis penelitian deskriptif analitik dengan pengambilan data secara retrospektif. Sampel penelitian ini di lakukan dengan cara 
memilih sebagian dari populasi. Data di analisis dengan menggunakan analisis univariat untuk memperoleh distribusi frekuensi gambaran pola umum dan sensitivitas terhadap antibiotik dan di dapatkan jumlah sampel sebanyak 284.

\section{HASIL}

Tabel 1. Distribusi jenis sampel periode Januari sd Maret $(n=284)$

\begin{tabular}{|c|c|c|c|}
\hline No. & $\begin{array}{l}\text { Jenis } \\
\text { Sampel }\end{array}$ & Jumlah & $\%$ \\
\hline 1 & Pus & 139 & 48.9 \\
\hline 2 & Sputum & 76 & 26.8 \\
\hline 3 & Darah & 45 & 15.8 \\
\hline 4 & Urine & 10 & 3.5 \\
\hline 5 & $\begin{array}{l}\text { Cairan } \\
\text { Tubuh }\end{array}$ & 9 & 2.1 \\
\hline \multirow[t]{2}{*}{6} & Feses & 5 & 1.8 \\
\hline & Jumlah & 284 & 100 \\
\hline
\end{tabular}

Jenis sampel terbanyak yaitu pus sebanyak 139 sampel (48\%), dan sampel terkecil adalah CT yaitu 3 sampel dengan persentasi $1.1 \%$.

Tabel 2. Distribusi jumlah pemeriksaan kultur berdasarkan asal ruangan periode Januari sd Maret $(n=284)$

\begin{tabular}{cccc}
\hline No. & $\begin{array}{c}\text { Jenis } \\
\text { Sampel }\end{array}$ & Jumlah & \% \\
\hline I. & $\begin{array}{c}\text { RUANG NON } \\
\text { ICU (Steril) }\end{array}$ & $\mathbf{( 1 9 7 )}$ & \\
\hline & Alamanda & 18 & 6.3 \\
Anyelir & 7 & 2.5 \\
& Aster & 2 & 0,7 \\
Bogenvil & 2 & 0,7 \\
Delima & 2 & 0,7 \\
Nuri & 3 & 1.2 \\
Gelatik & 8 & 2.8 \\
Kemuning & 9 & 3.2 \\
Kenanga & 19 & 6.7 \\
Kutilang & 26 & 9.2 \\
Manayun & 1 & 0,4 \\
Mawar & 11 & 3.9
\end{tabular}

\begin{tabular}{ccc} 
Melati & 17 & 6 \\
Murai & 13 & 4.6 \\
Perinatologi & 17 & 6 \\
Puri Betik & 39 & 13.8 \\
Hati & 1 & 0,4 \\
Seruni & 1 & 0,4 \\
Tulip & 1 & 0,4 \\
VIP A & $\mathbf{6 2}$ & $\mathbf{2 1 . 9}$ \\
\hline II. RUANG ICU & $\mathbf{( 1 1 0 )}$ & \\
(Steril) & $7(1)$ & 2,5 \\
NICU & $9(8)$ & 3.2 \\
\hline PICU (steril) & 6 & 2.1 \\
\hline III. Instansi & 6 & 100 \\
Rawat Jalan & &
\end{tabular}

Berdasarkan tabel di atas diketahui hasil pemeriksaan menunjukan bahwa dari 278 sampel di ruang ICU dan non ICU RSUD Abdul Moeloek Provinsi Lampung, jenis sampel tertinggi di ruang non ICU adalah ruang Puri Betik Hati yaitu 39 sampel dengan persentasi $13.8 \%$ dan yang terendah adalah ruang Mananyun, Seruni, Tulip, dan Vip A yaitu masing-masing 1 sampel dengan persentasi $0,4 \%$. ruang ICU yaitu 62 sampel dengan persentasi $21.9 \%$, dan yang terendah adalah ruang PICU 9 sampel dengan persentasi $3.2 \%$.

Tabel 3. Distribusi Jenis Bakteri yang tumbuh di Ruang Non ICU $(n=205)$

\begin{tabular}{|c|c|c|c|}
\hline NO. & Nama Bakteri & Jumlah & $\%$ \\
\hline 1 & Enterobacter sp & 68 & $33 \%$ \\
\hline 2 & Klebsiella sp & 34 & $16.4 \%$ \\
\hline 3 & $\begin{array}{l}\text { Proteus } \\
\text { mirabilis }\end{array}$ & 15 & $7,7 \%$ \\
\hline 4 & Escherichia coli & 15 & $7,2 \%$ \\
\hline 5 & $\begin{array}{c}\text { Enterobacter } \\
\text { cloacae }\end{array}$ & 14 & $6,7 \%$ \\
\hline 6 & $\begin{array}{l}\text { Klebsiella } \\
\text { pneumonia }\end{array}$ & 9 & $4,8 \%$ \\
\hline 7 & $\begin{array}{c}\text { Staphylococcus } \\
\text { aureus }\end{array}$ & 8 & $3.8 \%$ \\
\hline 8 & $\begin{array}{l}\text { Pseudomonas } \\
\text { luteola }\end{array}$ & 8 & $3,8 \%$ \\
\hline 9 & $\begin{array}{c}\text { Pseudomonas } \\
\text { aeruginosa }\end{array}$ & 6 & $2,9 \%$ \\
\hline 10 & Proteus sp & 3 & $0,8 \%$ \\
\hline 11 & $\begin{array}{c}\text { Providencia } \\
\text { stuartii }\end{array}$ & 3 & $1,2 \%$ \\
\hline 12 & $\begin{array}{c}\text { Citrobacter } \\
\text { koseri }\end{array}$ & 2 & $0.8 \%$ \\
\hline
\end{tabular}




\begin{tabular}{|c|c|c|c|}
\hline 13 & $\begin{array}{l}\text { Aeromonas } \\
\text { sobria }\end{array}$ & 2 & $0.8 \%$ \\
\hline 14 & $\begin{array}{l}\text { Aeromonas } \\
\text { hydrophila }\end{array}$ & 2 & $0.8 \%$ \\
\hline 15 & $\begin{array}{c}\text { Serratia } \\
\text { marcescens }\end{array}$ & 2 & $0,8 \%$ \\
\hline 16 & $\begin{array}{l}\text { Pasteurella } \\
\text { pneumatica }\end{array}$ & 2 & $0,8 \%$ \\
\hline 17 & $\begin{array}{l}\text { Sphingomonas } \\
\text { paucimobilis }\end{array}$ & 2 & $0,8 \%$ \\
\hline 18 & $\begin{array}{c}\text { Acinetobacter } \\
\text { baumanii }\end{array}$ & 2 & $0,4 \%$ \\
\hline 19 & $\begin{array}{c}\text { Staphylococcus } \\
s p\end{array}$ & 1 & $0,4 \%$ \\
\hline 20 & $\begin{array}{c}\text { Yersinia } \\
\text { enterocolitica }\end{array}$ & 1 & $0,4 \%$ \\
\hline 21 & $\begin{array}{c}\text { Pseudomonas } \\
s p\end{array}$ & 1 & $0,4 \%$ \\
\hline 22 & $\begin{array}{c}\text { Morganella } \\
\text { morganii }\end{array}$ & 1 & $0,4 \%$ \\
\hline 23 & $\begin{array}{l}\text { Serratia } \\
\text { forficula }\end{array}$ & 1 & $0,4 \%$ \\
\hline 24 & $\begin{array}{l}\text { Streptococcus } \\
\text { aureus }\end{array}$ & 1 & $0,4 \%$ \\
\hline 25 & $\begin{array}{l}\text { Serratia } \\
\text { fonticola }\end{array}$ & 1 & $0,4 \%$ \\
\hline 26 & $\begin{array}{l}\text { Providencia } \\
\text { rettgeri }\end{array}$ & 1 & $0,4 \%$ \\
\hline & Jumlah & 205 & $100 \%$ \\
\hline
\end{tabular}

Berdasarkan tabel di atas diketahui jenis bakteri menunjukan bahwa dari 219 sampel di non ICU RSUD Abdul Moeloek Provinsi lampung, jenis sampel tertinggi adalah bakteri Enterobacter cloacae yaitu 68 bakteri dengan persentasi $33 \%$, dan yang terendah bakteri Staphylococcus $s p$, Pseudomonas $s p$, Yersinia enterocolitica, Morganella morganii, Serratia forficula, Streptococcus aureus, Seratia fonticola, Acinetobacter baumanii, dan Providencia rettgeri yaitu 1 bakteri dengan persentasi $0,4 \%$.

Tabel 4. Distribusi Jenis Bakteri yang tumbuh di Ruang ICU $(n=79)$

\begin{tabular}{|c|c|c|c|}
\hline NO. & Nama Bakteri & Jumlah & $\%$ \\
\hline 1 & $\begin{array}{c}\text { Enterobacter } \\
\text { cloacae }\end{array}$ & 51 & 65.3 \\
\hline 2 & $\begin{array}{c}\text { Klebsiella } \\
\text { pneumoniae }\end{array}$ & 10 & 9.2 \\
\hline 3 & $\begin{array}{c}\text { Enterobacter } \\
\text { aerogenes }\end{array}$ & 2 & 2.4 \\
\hline 4 & $\begin{array}{l}\text { Proteus } \\
\text { mirabilis }\end{array}$ & 2 & 2.4 \\
\hline 5 & $\begin{array}{c}\text { Pseudomonas } \\
\text { aeruginosa }\end{array}$ & 2 & 2.4 \\
\hline
\end{tabular}

\begin{tabular}{|c|c|c|c|}
\hline 6 & $\begin{array}{c}\text { Seratia } \\
\text { marcescens }\end{array}$ & 2 & 2.4 \\
\hline 7 & $\begin{array}{l}\text { Pasteurella } \\
\text { pneumatica }\end{array}$ & 2 & 2.4 \\
\hline 8 & $\begin{array}{c}\text { Acinetobacter } \\
\text { baumannii }\end{array}$ & 2 & 2.4 \\
\hline 9 & Escherichia coli & 1 & 1.2 \\
\hline 10 & $\begin{array}{c}\text { Staphylococcus } \\
\text { aureus }\end{array}$ & 1 & 1.2 \\
\hline 11 & $\begin{array}{c}\text { Pseudomonas } \\
\text { luteola }\end{array}$ & 1 & 1.2 \\
\hline 12 & $\begin{array}{c}\text { Alcaligenes } \\
\text { faecalis }\end{array}$ & 1 & 1.2 \\
\hline 13 & $\begin{array}{c}\text { Yersinia } \\
\text { enterocolitica }\end{array}$ & 1 & 1.2 \\
\hline 14 & $\begin{array}{c}\text { Burkholderia } \\
\text { cepacia }\end{array}$ & 1 & 1.2 \\
\hline & Jumlah & 79 & 100 \\
\hline
\end{tabular}

Berdasarkan tabel di atas diketahui jenis bakteri menunjukan bahwa dari 78 sampel di ruang ICU RSUD Abdul Moeloek Provinsi Lampung, jenis sampel tertinggi adalah bakteri Enterobacter $s p$ yaitu 51 bakteri dengan persentasi $65,3 \%$, dan yang terendah bakteri Escherichia coli, Staphylococcus aureus, Pseudomonas luteola, Pasteurella pneumotropica, Alcaligenes faecalis, dan Yersinia enterocolitica yaitu 1 bakteri dengan persentasi $1,2 \%$.

Berdasarkan tabel 5 diketahui jenis bakteri menunjukan sensitivitas bakteri di ruang ICU RSUD Abdul Moeloek Provinsi Lampung, jenis bakteri Enterobacter cloacae memiliki sensitivitas tertinggi terhadap antibiotik Amikacin yaitu 37 (100\%) dan sensitivitas terendah terhadap antibiotik Ceftriaxone 2 (100\%), Enterobacter aerogenes memiliki sensitivitas tertinggi Amikacin yaitu 3 $(100 \%)$ terhadap antibiotik dan sensitivitas terendah terhadap antibiotik yaitu Aztreonam, Ertapenem, Ciprofloxaxine, Chloramphenicol, Tetracyclin, Amoxicillin, Cefotaxime, Netilmycin, Cefoperazone, Cefpirome yaitu 1 (100\%). Klebsiella pneumonia memiliki sensitivitas tertinggi terhadap antibiotik Meropenem yaitu 5 (83\%) dan sensitivitas terendah terhadap antibiotik, Sulbactam, dan Gentamicin yaitu 1 (25\%). Proteus mirabilis memiliki sensitivitas tertinggi terhadap antibiotikAmikacin dan Tetracyclin yaitu 
$2(100 \%)$ dan sensitivitas terendah terhadap antibiotik, Meropenem, , Gentamicin, Netilmycin, Cefoperazone, dan Cefpirome yaitu 1 (100\%), Acinetobacter baumannii memiliki sensitivitas tertinggi terhadap antibiotik Ciprofloxaxine dan Amikacin yaitu 2 $(100 \%)$, dan sensitivitas terendah terhadap antibiotik Amikacin, Gentamicin, Ciprofloxaxine, Tigecycline, dan seulfamethoxazole yaitu 1 (50\%).Pseudomonas aeruginosa memiliki sensitivitas tertinggi terhadap antibiotik Amikacin yaitu $2(100 \%)$ dan sensitivitas terendah terhadap antibiotik
Tazobactam, Gentamicin, dan Ciprofloxaxine yaitu 1 (100\%). Seratia marcescens memiliki sensitivitas tertinggi terhadap antibiotik Seulfamethoxazole yaitu $2(100 \%)$ dan sensitivitas terendah terhadap antibiotik Amikacin, Gentamicin, Ciprofloxaxine, dan Tigecycline yaitu 1 (100\%). Pasteurella pneumotropica memiliki sensitivitas tertinggi terhadap antibiotik Sulbactam, Tazobactam, Cefazolin, Ceftazidime, Ceftriaxone, Cefepime, Meropenem, Amikacin, Tigecycline, Nitrofurantion, dan Seulfamethoxazole yaitu 1 (100\%).

Tabel 5. Pola Resistensi Bakteri Terhadap Antibiotik berdasarkan Asal Ruangan ICU

\begin{tabular}{|c|c|c|c|c|c|c|c|c|c|c|c|c|c|c|c|c|}
\hline \multirow[t]{2}{*}{ Kode } & \multirow[t]{2}{*}{ Nama Antibiotik } & \multicolumn{2}{|c|}{ 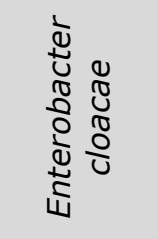 } & \multicolumn{2}{|c|}{ 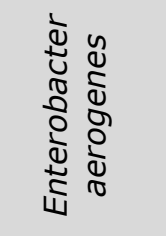 } & \multicolumn{2}{|c|}{ 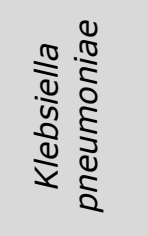 } & \multicolumn{2}{|c|}{ 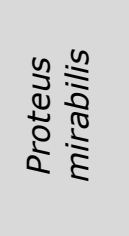 } & \multicolumn{2}{|c|}{ 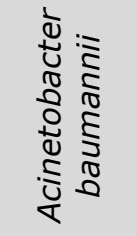 } & \multicolumn{2}{|c|}{ 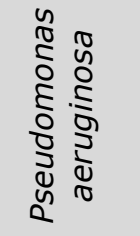 } & \multicolumn{2}{|c|}{ 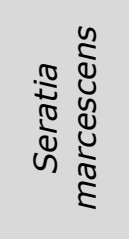 } & \multirow{2}{*}{ 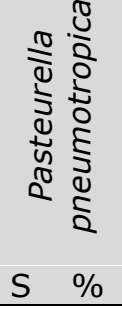 } \\
\hline & & $\mathrm{S}$ & $\%$ & $\mathrm{~S}$ & $\%$ & $\mathrm{~S}$ & $\%$ & $\mathrm{~S}$ & $\%$ & $S$ & $\%$ & $\mathrm{~S}$ & $\%$ & $\mathrm{~S}$ & $\%$ & \\
\hline 1 & Ampisilin & 4 & 100 & 0 & 100 & 1 & 50 & & & 0 & 100 & 0 & 100 & & & $\begin{array}{ll}0 & 100 \\
\end{array}$ \\
\hline 2 & Sulbactam & 5 & 100 & 0 & 100 & 1 & 25 & & & 0 & 100 & 0 & 100 & & & 1100 \\
\hline 3 & Tazobactam & & & 0 & 100 & 0 & 100 & & & 0 & 100 & 1 & 100 & & & 1100 \\
\hline 4 & Cefazolin & & & 0 & 100 & 0 & 100 & & & 0 & 100 & 0 & 100 & 0 & 100 & 1100 \\
\hline 5 & Ceftazidime & & & 0 & 100 & 0 & 100 & & & 0 & 100 & 0 & 100 & 0 & 100 & 1100 \\
\hline 6 & Ceftriaxone & 2 & 100 & 0 & 100 & 0 & 100 & & & 0 & 100 & 0 & 100 & 0 & 100 & 1100 \\
\hline 7 & Cefepime & & & 0 & 100 & 0 & 100 & & & 0 & 100 & 0 & 100 & 0 & 100 & 1100 \\
\hline 8 & Aztreonam & & & 1 & 100 & 1 & 33 & & & 0 & 100 & & & 0 & 100 & $\begin{array}{ll}0 & 100 \\
\end{array}$ \\
\hline 9 & Ertapenem & & & 1 & 100 & 0 & 100 & & & 0 & 100 & & & 0 & 100 & \\
\hline 10 & Meropenem & 12 & 100 & 2 & 100 & 5 & 83 & 1 & 100 & 0 & 100 & 0 & 100 & 0 & 100 & 1100 \\
\hline 11 & Amikacin & 37 & 100 & 3 & 100 & 5 & 62 & 2 & 100 & 2 & 100 & 2 & 100 & 1 & 100 & 1100 \\
\hline 12 & Gentamicin & 16 & 100 & 2 & 100 & 1 & 25 & 1 & 100 & 1 & 50 & 1 & 100 & 1 & 100 & $\begin{array}{ll}0 & 100 \\
\end{array}$ \\
\hline 13 & Ciprofloxaxine & 20 & 100 & 1 & 100 & 2 & 40 & & & 2 & 100 & 1 & 100 & 1 & 100 & $0 \quad 100$ \\
\hline 14 & Tigecycline & & & 2 & 100 & 0 & 100 & & & 1 & 50 & 0 & 100 & 1 & 100 & 1100 \\
\hline 15 & Nitrofurantion & & & 0 & 100 & 0 & 100 & & & 0 & 100 & 0 & 100 & 0 & 100 & 1100 \\
\hline 16 & Seulfamethoxazole & & & 0 & 100 & 3 & 100 & & & 1 & 50 & 0 & 100 & 2 & 100 & 1100 \\
\hline 17 & Chloramphenicol & 12 & 100 & 1 & 100 & 2 & 100 & & & & & & & & & \\
\hline 18 & Tetracyclin & 28 & 100 & 1 & 100 & 5 & 100 & 2 & 100 & & & & & & & \\
\hline 19 & Erytromycine & 3 & 100 & & & & & & & & & & & & & \\
\hline 20 & Amoxicillin & 8 & 100 & 1 & 100 & 2 & 100 & & & & & & & & & \\
\hline 21 & Cefotaxime & 3 & 100 & 1 & 100 & 1 & 100 & & & & & & & & & \\
\hline 22 & Cefadroxile & 12 & 100 & & & 1 & 100 & & & & & & & & & \\
\hline 23 & Netilmycin & 21 & 100 & 1 & 100 & 1 & 100 & 1 & 100 & & & & & & & \\
\hline 24 & Cefoperazone & 11 & 100 & 1 & 100 & 4 & 100 & & 100 & & & & & & & \\
\hline 25 & Cefpirome & 35 & 100 & 1 & 100 & & & 1 & 100 & & & & & & & \\
\hline
\end{tabular}




\section{Tabel 6. Pola Resistensi Bakteri Terhadap Antibiotik berdasarkan Asal Ruangan Non ICU}

\begin{tabular}{|c|c|c|c|c|c|c|c|c|c|c|c|c|c|c|c|c|c|}
\hline \multirow[t]{2}{*}{ Kode } & \multirow[t]{2}{*}{$\begin{array}{c}\text { Nama } \\
\text { Antibiotik }\end{array}$} & \multicolumn{2}{|c|}{ 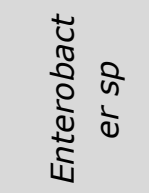 } & \multicolumn{2}{|c|}{ 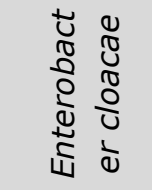 } & \multicolumn{2}{|c|}{ 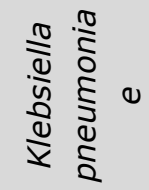 } & \multicolumn{2}{|c|}{ 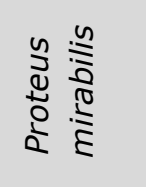 } & \multicolumn{2}{|c|}{ 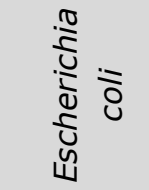 } & \multirow[t]{2}{*}{ 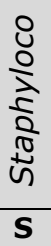 } & \multirow{2}{*}{ 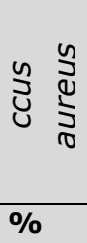 } & \multicolumn{2}{|c|}{ 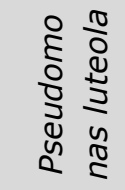 } & \multicolumn{2}{|c|}{$\frac{\frac{0}{0}}{\frac{0}{\frac{1}{2}}}$ n } \\
\hline & & $\mathbf{S}$ & $\%$ & $\mathbf{S}$ & $\%$ & $\mathbf{S}$ & $\%$ & $\mathbf{S}$ & $\%$ & $\mathbf{S}$ & $\%$ & & & $\mathbf{S}$ & $\%$ & $\mathbf{S}$ & $\%$ \\
\hline 1 & Ampisilin & 11 & 100 & 1 & 100 & 0 & 100 & 3 & 100 & 2 & 18 & & & 1 & 25 & & 83 \\
\hline 2 & Sulbactam & 8 & 100 & & & 1 & 12 & 2 & 100 & 5 & 62 & & & 5 & 62 & 4 & 26 \\
\hline 3 & Tazobactam & 0 & 100 & & & 3 & 37 & 1 & 100 & 7 & 70 & & & 4 & 57 & 6 & 42 \\
\hline 4 & Cefazolin & 4 & 66 & & & 1 & 12 & 0 & 100 & 3 & 27 & & & 5 & 62 & 3 & 21 \\
\hline 5 & Ceftazidime & 0 & 100 & & & 1 & 12 & 1 & 100 & 2 & 20 & & & 3 & 50 & 3 & 21 \\
\hline 6 & Ceftriaxone & 7 & 70 & & & 1 & 12 & 2 & 100 & 2 & 18 & 3 & 100 & 4 & 57 & 3 & 31 \\
\hline 7 & Cefepime & 1 & 100 & & & 1 & 12 & 2 & 100 & 4 & 36 & & & 6 & 75 & 3 & 21 \\
\hline 8 & Aztreonam & 6 & 66 & & & 1 & 12 & 4 & 100 & 2 & 18 & & & 2 & 66 & 3 & 38 \\
\hline 9 & Ertapenem & 4 & 80 & & & 5 & 62 & 1 & 50 & 10 & 90 & & & 1 & 50 & 9 & 64 \\
\hline 10 & Meropenem & 38 & 97 & & & 5 & 62 & 11 & 100 & 11 & 91 & 3 & 100 & 5 & 71 & 9 & 85 \\
\hline 11 & Amikacin & 67 & 100 & 11 & 100 & 9 & 100 & 13 & 100 & & & 7 & 100 & 7 & 87 & 33 & 100 \\
\hline 12 & Gentamicin & 25 & 86 & 5 & 100 & 5 & 62 & 2 & 100 & 8 & 72 & 1 & 100 & 4 & 50 & 9 & 100 \\
\hline 13 & Ciprofloxaxine & 28 & 100 & 10 & 100 & 5 & 55 & 5 & 100 & 3 & 27 & & & 3 & 37 & 16 & 72 \\
\hline 14 & Tigecycline & 5 & 100 & & & 5 & 62 & 1 & 100 & 14 & 100 & & & 8 & 100 & 11 & 78 \\
\hline 15 & Nitrofurantion & 3 & 42 & & & 6 & 75 & 1 & 100 & 8 & 80 & & & 8 & 100 & 3 & 42 \\
\hline 16 & Sulfamethoxazole & 0 & 100 & & & 2 & 25 & 1 & 100 & 5 & 45 & & & 6 & 75 & 7 & 50 \\
\hline 17 & Chloramphenicol & 15 & 100 & 1 & 100 & 4 & 50 & 2 & 100 & 1 & 100 & & & & & 8 & 100 \\
\hline 18 & Tetracyclin & 40 & 100 & 2 & 100 & 1 & 100 & 6 & 100 & & & 3 & 100 & & & 18 & 100 \\
\hline 19 & Erytromycine & 6 & 100 & 1 & 100 & 1 & 100 & & & & & & & & & 1 & 100 \\
\hline 20 & Amoxicillin & 19 & 100 & 3 & 100 & & & 2 & 100 & & & 3 & 100 & & & 7 & 100 \\
\hline 21 & Cefotaxime & 8 & 100 & 6 & 100 & 1 & 100 & & & & & & & & & 4 & 100 \\
\hline 22 & Cefadroxile & 29 & 100 & 9 & 100 & & & 4 & 100 & & & 3 & 100 & & & 12 & 100 \\
\hline 23 & Netilmycin & 27 & 100 & 11 & 100 & & & & & & & 1 & 100 & & & 12 & 100 \\
\hline 24 & Cefoperazone & 36 & 100 & 5 & 100 & & & 6 & 100 & & & 3 & 100 & & & 15 & 100 \\
\hline 25 & Cefpirom & 65 & 100 & 10 & 100 & & & 12 & 100 & 1 & 100 & 6 & 100 & & & 1 & 100 \\
\hline
\end{tabular}

Berdasarkan tabel diketahui jenis bakteri menunjukan sensitivitas bakteri di ruang non ICU RSUD Abdul Moeloek Provinsi Lampung, jenis bakteri Enterobacter $s p$ memiliki sensitivitas tertinggi Amikacin yaitu terhadap antibiotik yaitu $67(100 \%)$ dan sensitivitas terendah terhadap antibiotik Cefepime yaitu 1 (100\%). Enterobacter cloacae memiliki sensitivitas tertinggi terhadap antibiotik Amikacin dan Netilmycin yaitu 11 $(100 \%)$ dan sensitivitas terendah terhadap antibiotik Ampisilin, Chloramphenicol, dan Erytromycine yaitu $1(100 \%)$. Klebsiella pneumoniae memiliki sensitivitastertinggi terhadap antibiotik Amikacin yaitu $9(100 \%)$ dan sensitivitas terendah terhadap antibiotik Sulbactam, Cefazolin,
Ceftazidime, Ceftriaxone, Cefepime, Aztreonam, Tetracyclin, Erytromycine, dan Cefotaxime yaitu 1 (100\%). Proteus mirabilis memiliki sensitivitas tertinggi terhadap antibiotik Amikacin yaitu $13(100 \%)$ dan sensitivitas terendah terhadap antibiotik Tazobactam, Ceftazidime, Ertapenem, Tigecycline, Nitrofurantion, dan Sulfamethoxazole yaitu 1 (100\%). Escherichia coli memiliki sensitivitas tertinggi terhadap antibiotik Tigecycline yaitu $14 \quad(100 \%)$ dan sensitivitas terendah terhadap antibiotik Chloramphenicol dan Cefpirom yaitu 1 (100\%). Staphylococcus aureus memiliki sensitivitas tertinggi terhadap antibiotik Amikacin yaitu $7(100 \%)$ dan sensitivitas terendah terhadap antibiotik Ciprofloxaxine yaitu 1 
(100\%), Pseudomonas luteola memiliki sensitivitas tertinggi terhadap antibiotik Tigecycline dan Nitrofurantion yaitu 8 $(100 \%)$ dan sensitivitas terendah terhadap antibiotik Ampisilin yaitu 1 (25\%). Klebsiella sp memiliki sensitivitas tertinggi terhadap antibiotik Amikacin yaitu 33 (100\%) dan sensitivitas terendah terhadap antibiotik Erytromycine dan Cefpirom yaitu $1(100 \%)$. Berdasarkan tabel 7 di bawah didapatkan prevalensi jenis kuman (+) ESBL sebanyak 17 di RSUD Abdul Moeloek Provinsi Lampung. Yang tertinggi Bakteri Klebsiella pneumonia sebanyak 9 dengan persentase 47 yang, terendah Klebsiella sp sebanyak 1 dengan persentase $2.9 \%$. Enterobacter cloacea sebanyak 1 sampel dengan persentase $1.5 \%$.

Tabel 7. Prevalensi kuman (+) ESBL

\begin{tabular}{lccc}
\hline NO. & Bakteri & ESBL (\%) & Jumlah Bakteri (\%) \\
\hline 1 & Klebsiella pneumoniae & $9(47 \%)$ & $19(53 \%)$ \\
2 & Escherichia coli & $6(37 \%)$ & $16(63 \%)$ \\
3 & Klebsiella sp & $1(2,9 \%)$ & $34(97,1 \%)$ \\
4 & Enterobacter cloacea & $1(1,5 \%)$ & $65(98,5 \%)$ \\
\hline & Jumlah & $17(12 \%)$ & $134(88 \%)$ \\
\hline
\end{tabular}

\section{PEMBAHASAN}

Berdasarkan hasil perbandingan pola sensitivitas bakteri terhadap antibiotik di bagian Mikrobiologi laboratorium Patologi Klinik RSUD DR. H. Abdul Moeloek Provinsi Lampung periode januari-maret tahun 2019 di peroleh kesimpulan sebagai berikut:

Penelitian yang di lakukan ni nengah dwi diruang ICU RSUP sanglah denpasar Bali pada bulan AgustusOktober 2013 di dapatkan Spesimen yang hasil kultir positif terbanyak dari sputum $(44 \%)$, darah $(28 \%)$, urine $(12 \%)$, dan pus $(18 \%)$. Dari hasil penelitian yang dilakukan Mutia zahra pada tahun 2016 di RSUD DR.H Abdul Moeloek Provinsi Lampung didapatkan Jumlah sampel terbanyak yaitu sampel pus sebanyak 170 sampel (55.2\%). darah sebanyak 43 sampel $(13,10 \%)$, Urin 32 sampel $(10,4 \%)$, Sputum 60 sampel $(19,5 \%)$, dan Cairan tubuh 3 sampel $(0,97 \%)$.

Hasil yang sama di dapatkan dari penelitian ini bahwa berdasarkan data spesimen yang terdapat dalam hasil kultur selama periode Januari-Maret tahun 2019 adalah pus sebanyak 139 sampel (48.9\%), sputum sebanyak 76 $(26.8 \%)$, darah sebanyak $45(15.8 \%)$, urine sebanyak $10(3.5 \%)$, cairan tubuh sebanyak $9(2.1 \%)$, dan feses sebanyak 5 (1.8\%). Dari hasil penelitian di kelompokan berdasarkan ruangan yang dilakukan Mutia zahra pada tahun 2016 di RSUD DR.H Abdul Moeloek Provinsi Lampung di dapatkan bakteri terbanyak terdapat di ruang ICU yaitu 45 sampel dengan presentase $16,8 \%$. Diikuti dengan ruangan Kutilang 40 sampel $(12,10 \%)$ .Ruang Alamanda 39 sampel (12,7\%). Ruang Mawar 27 sampel (8,8\%). Ruang Melati 22 sampel (7,1\%). Ruang Gelatik 18 sampel (5,8\%). Ruang Murai 18 sampel $(5,8 \%)$. Dari hasil penelitian yang dilakukan dikelompokan berdasarkan ruangan oleh Gizar niam di RSUD Dr. H Abdul Moeloek Provinsi lampung pada bulan April-Juni tahun 2018213 sampel, ruangan ICU tertinggi yaitu 46 sampel (22\%), mawar 28 sampel (13\%), melati 19 sampel (9\%), IRJ 15 sampel (7\%), kutilang 14 sampel (7\%).

Hasil yang sama juga di dapatkan bahwa berdasarkan hasil dari penelitian ini dari 284 sampel yang di kelompokan berdasarkan ruangan, ruang ICU sebanyak 65 sampel $(22.9 \%)$, NICU sebanyak 10 sampel $(3.6 \%)$, dan ruang PICU sebanyak 9 sampel (3.2\%). Ruang non ICU terdiri dari ruang Puri betik hati sebanyak 39 sampel $(13.8 \%)$ ruang kutilang 26 
sampel $(9.2 \%)$, ruang kenanga 19 sampel $(6.7 \%)$, ruang alamanda 18 sampel $(6.3 \%)$, ruang melati dan perinatologi 17 sampel (6\%), ruang murai 13 sampel $(4.6 \%)$, ruang mawar 11 sampel $(3.9 \%)$, ruang kemuning 9 sampel $(3.2 \%)$, ruang gelatik 8 sampel $(2.8 \%)$, ruang anyelir 7 sampel $(2.5 \%)$, ruang nuri 3 sampel $(1.2 \%)$, ruang aster bogenvil dan delima masing-masing 2 sampel $(0,7 \%)$, ruang Manayun Seruni Tulip dan Vip A masing-masing 1 sampel $(0,4 \%)$. Instansi rawat jalan 6 sampel $(2.1 \%)$.

Berdasarkan data pola kuman yang dilakukan muti zahra di Rumah Sakit Dr. H. Abdoel Moeloek provinsi Lampung periode Januari - Juli 2016, didapatkan kuman terbanyak di ruangan adalah Staphylococcus $s p$ sebanyak 134 sampel dengan presentase $43,5 \%$, dan yang terendah bakteri Escherichia coli sebanyak 5 sampel dengan presentase $1,6 \%$.

Berdasarkan data pola kuman yang dilakukan Gizar niam di Rumah Sakit Dr. H. Abdoel Moeloek provinsi Lampung periode April - Juni tahun 2018 adalah Enterobacter sp sebanyak $80(38 \%)$, dan yang terendah bakteri Escherichia coli sebanyak 3 sampel (1\%). Sementara pada sebuah penelitian di ICU RS Dr. Wahidin Sudirohusodo Makassar pada tahun 2009, ditemukan bahwa Klebsiella pneumonia adalah bakteri terbanyak $(28,3 \%)$, dan yang lebih jarang ditemukan adalah Pseudomonas aeroginosa dan Alkaligenes faecalis masing-masing sebanyak (3,3\%).

Hasil yang berbeda di dapatkan dari penelitian ini Berdasarkan data pola kuman terbanyak yang di temukan selama periode januari- maret tahun 2019 di RSUD DR. H. Abdul Moeloek Provinsi Lampung, di ruang ICU adalah Enterobacter cloacae yaitu 68 sampel $(33 \%)$, dan yang terendah bakteri Staphylococcus sp, Pseudomonas $s p$, Yersinia enterocolitica, Morganella morganii, Serratia forficula, Streptococcus aureus, Seratia fonticola, Acinetobacter baumanii, dan Providencia rettgeri yaitu 1 sampel $(0,4 \%)$, dan di ruang non ICU Enterobacter $s p$ yaitu 51 sampel $(65,3 \%)$, dan yang terendah bakteri
Escherichia coli, Staphylococcus aureus, Pseudomonas luteola, Pasteurella pneumotropica, Alcaligenes faecalis, dan Yersinia enterocolitica yaitu 1 sampel $(1,2 \%)$.

Berdasarkan data pola kuman yang dilakukan Mutia Zahra di Rumah Sakit Dr. H. Abdoel Moeloek provinsi Lampung periode Januari - Juli 2016, Berdasarkan hasil uji sensitifitas terhadap antibiotik didapatkan pola bakteri yang sudah resisten adalah Penisilin dengan presentase $(100 \%)$, Ampisilin dengan presentase $(83 \%)$, Amoksilin dengan presentase $(78,6 \%)$, Cefotaxime dengan presentase $(33 \%)$, Tetrasiklin dengan presentase $(28,6 \%)$, Ceftriaxone dengan presentase $(22,7 \%)$. Dan Antibiotik yang masih sensitif yaitu, Meropenem dengan presentase $(75 \%)$.

Berdasarkan hasil uji sensitivitas bakteri yang di lakukan Gizar niam di Rumah Sakit Dr. H. Abdoel Moeloek provinsi Lampung periode April-Juni 2018 yang di temukan pada penelitian di dapatkan persentase sensitive bakteri terhadap antibiotik, Alcaligenes sp terhadap Meropenem (76\%), Staphylococcus sp terhadap Meropenem (75\%), Proteus sp terhadap Meropenem (67\%), Klebsiella sp terhadap Sulbactam-cefpirom $(64 \%), \quad E$ Coli terhadap Amikasin $(67 \%)$, dan Streptococcus sp terhadap Ampisilin (67\%).

Hasil berbeda didapatkan dari penelitian ini berdasarkan hasil uji sensitivitas kuman selama periode januari-maret tahun 2019 di RSUD DR. $\mathrm{H}$. Abdul Moeloek Provinsi Lampung yang di temukan pada penelitian ini didapatkan persentase sensitivitas bakteri terhadap antibiotik sebagai berikut :di ruang non ICU bakteri Enterobacter $s p$ sensitivitas tertinggi terhadap antibiotik amikacin yaitu 37 dengan persentase $(100 \%)$, dan sensitivitas terendah terhadap antibiotik Ceftriaxone yaitu 2 persentasi (100\%). Di ruang ICU Bakteri Enterobacter cloacae memiliki sensitivitas tertinggi terhadap antibiotik amikacin yaitu 37 dengan persentasi $100 \%$, dan sensitivitas terendah terhadap antibiotik Ceftriaxone yaitu 2 dengan persentasi $100 \%$. 


\section{KESIMPULAN}

Berdasarkan hasil perbandingan pola sensitivitas bakteri terhadap antibiotik di bagian Mikrobiologi laboratorium Patologi Klinik RSUD DR. H. Abdul Moeloek Provinsi Lampung periode januari-maret tahun 2019 di peroleh kesimpulan sebagai berikut:

1. Berdasarkan data kultur di dapatkan jenis bakteri yang terdapat di ruang non ICU yaitu Enterobacter sp 68 sampel ( $33 \%)$, Klebsiella sp 34 sampel (16.4\%), Enterobacter cloacea 14 sampel $(6,7 \%)$ Proteus mirabilis 16 sampel $(7,7 \%)$, Escherichia coli 15 sampel $(7,2 \%)$. Bakteri yang terdapat di Ruang ICU adalah Enterobacter cloacea 51 sampel (65.3\%), Klebsiella pneumonia 9 sampel $(9.2 \%)$, Pseudomonas aeruginosa, Seratia marcescens, Pasteurella pneumatica, Acinetobacter baumannii, Enterobacter aerogenes dan Proteus mirabilis masingmasing 2 sampel (2.4\%), Escherichia coli, Staphylococcus aureus dan Pseudomonas luteola, Alcaligenes faecalis, Yersinia enterocolitica, dan Burkholderia cepacia masing-masing 1 sampel $(1.2 \%)$.

2. Berdasarkan data hasil kultur selama periode Januari-Maret tahun 2019 ditemukan pola sensitivitas bakteri di ruang ICU dan non ICU yaitu pola kuman terbanyak di ruang ICU adalah Enterobacter cloacea tingkat sensitivitas tertinggi terhadap antibiotik Amikacin ruang non ICU adalah Enterobacter $s p$ tingkat sensitivitas tertinggi terhadap antibiotik Netilmycin.

3. Terdapat perbedaan pola bakteri dan pola sensitivitas bakteri terhadap antibiotik antara ruang ICU dan non ICU periode januarimaret tahun 2019 di RSUD DR.H. Abdul Moeloek Provinsi Lampung.

\section{SARAN}

Bagi instansi terkait perlu adanya kontrol terhadap antibiotik dengan baik dan benar untuk mengurangi kerjadian resistensi antibiotik. Bagi kalangan medis perlu adanya informasi tentang perkembangan pola bakteri yang sensitive dan bakteri yang sudah resisten terhadap antibiotik sehingga penggunaan antibiotik tepat sasaran. Perlu dilakukan penelitian tentang pola sensitivitas bakteri di rumah sakit lainnya untuk mengetahui bakteri yang masih sensitive dan bakteri yang sudah resisten terhadap antibiotik.

\section{DAFTAR PUSTAKA}

Nengah. (2016). Pola Mikroba Pasien Yang Dirawat Di Intensive Care Unit (Icu) Serta Kepekaannya Terhadap Antibiotik Di Rsup Sanglah Denpasar Bali AgustusOktober 2013. E-jurnal medika. 5(4): 5-6.

Kemenskes RI. 2013. Riskesdas (Riset kesehatan dasar). Jakarta: 1

Tjay H.T, Raharja K, 2007. Obat-obat Penting; Khasiat, Penggunaan, dan Efek Sampingnya. Edisi VI. Jakarta. Elex Media Komputindo.

Septi D. (2015). Pola resistensi bakteri terhadap antibiotik pada penderita infeksi luka operasi (ilo) di rumah sakit $x$ periode agustus 2013-agustus. [Skripsi]. Surakarta : Fakultas Farmasi Universitas Muhammadiyah surakarta.

Zahra, M 2018. Analisis Pola Kuman dan Pola Resistensi Pada Hasil Pemeriksaan Kultur Resistensi Di Laboratorium Patologi Klinik Rumah Sakit Dr. H. Abdoel Moeloek Provinsi Lampung Periode Januari - Juli 2016. Jurnal IImu Kedokteran dan Kesehatan. 5(2): 84-85.

WHO. 2011. Collaborating Centre for Drug Statistics Methodology. ATC/DDD index 2011. 